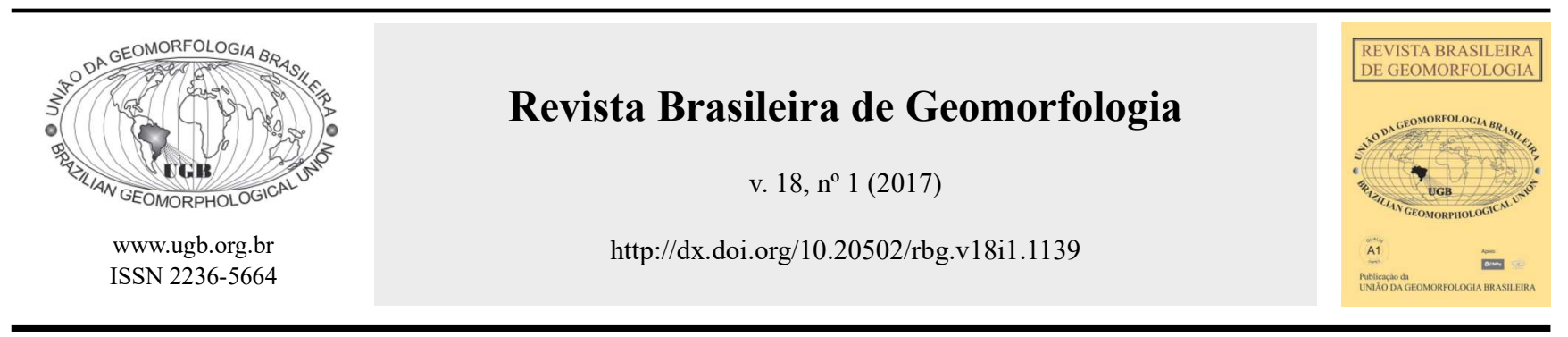

\title{
RIVER FUNCTIONING ANALYSIS FROM SUSPENDED SEDIMENT AND WATER DISCHARGE STUDY: THE CASE OF THE IVAÍ RIVER, SOUTHERN BRAZIL
}

\section{ANÁLISE DO FUNCIONAMENTO FLUVIAL A PARTIR DO ESTUDO DA DESCARGA DE ÁGUA E SEDIMENTO SUSPENSO: O CASO DO RIO IVAÍ, SUL DO BRASIL}

Isabel Terezinha Leli

Departamento de Geografia, Universidade Estadual do Oeste do Paraná Rua Pernambuco, 1777, Marechal Cândido Rondon, Paraná. CEP: 85960-000. Brasil

Email: isabeltleli@gmail.com.br

José Cândido Stevaux Departamento de Geografia, Universidade Estadual de Maringá Av. Colombo, 5790, Maringá, Paraná. CEP: 87020-900. Brasil Email:josecstevaux@gmail.com.br

Édipo Henrique Cremon Instituto Federal de Goiás Rua 75, 46, Goiânia, Goiás. CEP: 74055-110. Brasil Email:edipocremon@yahoo.com.br

Maria Tereza da Nóbrega

Departamento de Geografia, Universidade Estadual de Maringá Av. Colombo, 5790, Maringá, Paraná. CEP: 87020-900. Brasil

Email:mtnobrega@uol.br

\section{Informações sobre o Artigo}

Recebido (Received):

16/02/2017

Aceito (Accepted):

10/03/2016

\section{Keywords:}

Ivaí River; Discharge Regime; Suspended Sediment; Plateau River; Paraná River Basin.

Palavras-chave:

Rio Ivaí; Regime de Descarga de Água; Sedimento Suspenso; Rio de Platô; Bacia do Rio.

\begin{abstract}
:
This paper presents the spatial distribution of liquid and solid (suspended load) discharge in the Ivaí River Basin, and its implication in the functioning of this river system. The Ivaí is a typical medium-size river of the basaltic plateau, on the left side of the Paraná River Basin in southern Brazil. The data relating to water discharge and concentration of suspended sediment come from 19 gauging stations controlled by the former Superintendence of Water Resources and Environmental Sanitation Development SUDERHSA, today Water Institute of Paraná. The river drains an area of $36,587 \mathrm{~km}^{2}$, and its average discharge during the study period (19742008) was $702.9 \mathrm{~m}^{3} \mathrm{~s}^{-1}$. The specific discharge $(\mathrm{Qsp}=\mathrm{Qm}: \mathrm{Ab})$ varied uniformly between 0.01 and $0.02 \mathrm{~m}^{3} \mathrm{~s}^{-1} \mathrm{~km}^{-2}$, however, an anomalous result of $0.11 \mathrm{~m}^{3} \mathrm{~s}^{-1} \mathrm{~km}^{-2}$ was identified. Most of the water that enters the
\end{abstract}


Ivaí River comes from the smaller sub-basins $\left(<500 \mathrm{~km}^{2}\right)$, and the specific discharge from the tributaries decreases from upstream to downstream, from 0.028 to $0.015 \mathrm{~m}^{3} \mathrm{~s}^{-1} \mathrm{~km}^{-2}$. Correlations are high between the annual production of suspended sediment versus average discharge $\left(\mathrm{R}^{2}=0.97\right)$ for all river gauging stations, and the contribution of suspended load versus basin area $\left(\mathrm{R}^{2}=0.95\right)$. This suggests that the elongate morphology of the basin is main variable controlling of water and sediment distribution. The water and suspended sediment discharge of the Ivaí River is similar to those dry-wet, temperate climate river in the world. A good correlation was also obtained when the river was compared with others plateau river in the world. The results make a great contribution to the management and planning projects for many basaltic-plateau rivers along the eastern side of the upper Paraná Basin, Brazil.

\section{Resumo:}

Este estudo apresenta a distribuição espacial de descarga líquida e sólida (carga suspensa) na Bacia do rio Ivaí, e suas implicações no funcionamento deste sistema fluvial. O Ivaí é um rio de porte médio, típico de platô basáltico no lado oriental da Bacia do Rio Paraná no sul do Brasil. Os dados referentes à descarga de água e concentração de sedimentos em suspensão são provenientes de 19 estações fluviométricas, no período em que foram controladas pela antiga Superintendência de Desenvolvimento de Recursos Hídricos e Saneamento Ambiental - SUDERHSA, hoje Instituto das Águas do Paraná. O rio Ivaí drena uma área de $36,587 \mathrm{~km}^{2}$, e sua vazão média durante o período (1974-2008) foi 702,9 $\mathrm{m}^{3} \mathrm{~s}^{-1}$. A descarga específica $(\mathrm{Qsp}=\mathrm{Qm}: \mathrm{Ab})$ variou uniformemente entre 0,01 e $0,02 \mathrm{~m}^{3} \mathrm{~s}^{-1} \mathrm{~km}^{-2}$, no entanto, um resultado anômalo de $0,11 \mathrm{~m}^{3} \mathrm{~s}^{-1} \mathrm{~km}^{2}$ foi identificado. A maior parte da água que entra no rio Ivaí vem das pequenas sub-bacias $\left(<500 \mathrm{~km}^{2}\right)$, e a descarga específica das bacias afluentes diminui de montante para jusante, 0,028 e $0,015 \mathrm{~m}^{3} \mathrm{~s}^{-1} \mathrm{~km}^{-2}$. As correlações são altas, tanto na produção anual de sedimentos em suspensão versus descarga média $\left(\mathrm{R}^{2}=0,97\right)$, e a contribuição da carga suspensa por trecho versus área da bacia $\left(\mathrm{R}^{2}=0,95\right)$. Isto sugere que a morfologia alongada da bacia é a principal variável de controle para os sedimentos e água. O volume de descarga líquida e carga suspensa do Ivaí é compatível com outros rios do mundo localizados em regiões de clima seco e temperado-húmido. Uma boa correlação foi também obtida quando o rio foi comparado com outros rios de platô do mundo. Os resultados deste estudo contribuem para os projetos de gestão e planejamento para muitos rios de platô basáltico do lado oriental da alta Bacia do Rio Paraná, Brasil.

\section{Introduction}

The understanding of the hydrological regime of water and sediment of a hydrographic basin is the base for environmental questions concerning floodplain-channel coupling in terms of connectivity processes (NEIFF \& POI DE NEIFF, 2003; STEVAUX et al., 2013), as well as the regional economic, social and cultural structure (DOWNS \& GREGORY, 2004).

Medium-sized river systems running over basaltic plateau are very common in the Southern Brazil, and they constitute all the tributaries on the left-hand side of the Upper Paraná River Basin (Figura 1). The aggressive Brazilian hydroelectric policy resulted in the rapid construction of hundreds of large dams spread over the Upper Paraná River Basin (Figura 1), more specifically in its tributaries in the basaltic plateau. Among several impacts in the fluvial system, dam construction reduced the suspended load in the Paraná River from $90 \mathrm{mg} \mathrm{L}^{-1}$ to $0.5 \mathrm{mg.L-1}$ (STEVAUX et al., 2009), with irreversible consequences to the river's ecology (AGOSTINHO et al., 2004; STEVAUX et al., 2013). The majority of these medium-sized tributaries (Qm 500-1000 $\left.\mathrm{m}^{3} \mathrm{~s}^{-1}\right)$ were not studied in terms of hydrosedimentological and ecological functioning before the completion of the dams construction. The construction of many other dams are in the planning stages for the Ivaí, Piquirí, Iguaçu and Pelotas-Uruguay Rivers (the last one belonging to the Uruguay River Basin) over the next few years. From this perspective, a more accurate study concerning water and suspended sediment regime and dynamics is needed in order to cope with the resulting changes in the Upper Paraná left-hand tributaries in Brazil. However, all these rivers already have one or more dams which would harm the quantification and 
modeling of hydrosedimentary dynamics. The Ivaí River is an exception. Even with a relatively high hydroelectric potential of $900 \mathrm{MW}$ (COPEL, 1984), and a longitudinal profile with narrow rocky valleys and rapids in its upper and middle courses, its drainage basin remains practically in its natural condition, with only a few small dams in some tributaries.

Generally, studies relating to water and discharge of suspended sediment, at least in tropical mega-rivers in Brazil, such as the Amazon ( $\left.\mathrm{Qm} 209,000 \mathrm{~m}^{3} \mathrm{~s}^{-1}\right)$, Madeira $\left(\mathrm{Qm} 32,000 \mathrm{~m}^{3} \mathrm{~s}^{-1}\right)$, Negro $\left(28,400 \mathrm{~m}^{3} \mathrm{~s}^{-1}\right)$ and Japura (Qm $18,600 \mathrm{~m}^{3} \mathrm{~s}^{-1}$ ) (LATRUBESSE, 2009), are supported by data collected from a small number of gauging stations which are normally processed without much understanding of their spatial dynamics (FILIZOLA, 1999). However, since these rivers have such large channels, normally wider than $1 \mathrm{~km}$, the use of remote sensing tools compensates for the lack of sufficient gauging station data (MONTANHER et al., 2014, 2017; PARKER \& LATRUBESSE, 2014). However, these methods are not applicable in medium-sized rivers where the pixel resolution is normally larger than the channel width (ESPINOZZA et al., 2012). Considering the above, this paper deals with important issues such as: (a) the spatial distribution of suspended load in a typical basaltic plateau river on left-hand side of the Paraná River Basin; (b) the methods used in the study of suspended load in medium-sized rivers flowing over rocks; and (c) the importance of the Ivaí River as the main contributor of suspended load to the upper Paraná River.

\section{Background information}

The Ivaí River runs 798 km, crossing the Brazilian sedimentary-basaltic plateau that covers most of the Southern Brazil. With an annual average discharge of $702.9 \mathrm{~m}^{3} \mathrm{~s}^{-1}$ (1974-2008), it drains an area of 36,587 $\mathrm{km}^{2}$. The relief amplitude is $930 \mathrm{~m}$ with the headwater at the Boa Esperança Mountains (1,160 m a.s.l.) in the Third Paraná Highland and the mouth in the Paraná River at $230 \mathrm{~m}$ a.s.l. Although the Ivaí River does not have any dams, about $75 \%$ of its basin is occupied by agriculture and pasture lands, especially in the low and middle sectors. Because of the steep relief, the upper sector is sparsely occupied by cattle pasture. Some authors have divided the Ivaí River Basin according to on land use and geomorphology, and in relief-lithology relation (MEURER, 2008, 2010; MEURER et al., 2011). In this paper, we have used the triple division: upper, middle and lower basins (Table 1, and see Figura 2).

Geological-tectonic control for left-hand side tributaries of the Paraná River: The Paraná Sedimentary Basin is spread across $2,000,000 \mathrm{~km}^{2}$ of southern Brazil. It is a Paleozoic-Mesozoic geotectonic unit that contains the largest basaltic plateau in the world which was generated during the breakdown of the Gondwana Continent in the Mesozoic Age (Figura 1). The basalt has a maximum of $2000 \mathrm{~m}$ thick, spread over 1,200,000 km² in Brazil, Uruguay, Argentina and Paraguay (PONTELLI \& PAISANI, 2015). The geological basin has an elliptical form with the Paraná River running NE-SW along its longer axis. The basalt exposition is asymmetric, developing predominantly in the eastern side of the basin (Figura 1). The rising of the Serra do Mar Mountains (900-1000 m) on the Atlantic border during the Mio-Pliocene Age (BRAUN, 1971) generated an extensive westward monoclinal surface that, together with NW-SE structural lineaments (FERREIRA, 1982), created the formation of long tributary rivers $(>800$ $\mathrm{km}$ long) such as the Grande $(1360 \mathrm{~km})$, Tietê $(1150 \mathrm{~km})$, Paranapanema (929 km), Ivaí (798 km), Piquirí (660 km), Iguaçu $(1320 \mathrm{~km})$ and Pelotas-Uruguay $(2270 \mathrm{~km})$ rivers (the last being the tributary of the La Plata River). On the other hand, the Maracajú Mountains (900 m) rising 250 $\mathrm{km}$ west of the Paraná River, separates the Paraguay River Basin from the Paraná Basin, which originated during the Mio-Pliocene Age (Stevaux, 1994), and also generated a right-hand side drainage network of small rivers (Amambaí, Ivinhema, Sucuri and Iguatemi rivers $200-300 \mathrm{~km}$ long) that run over Cenozoic sandstone that covers the basaltic rocks (Figura 1).

\section{Data Provenance and Methods}

In this study, we used the historical series of discharge, concentration of suspended sediment, and rainfall data from the former SUDERHSA network of gauging stations. Gauging stations have different historical series intervals for water discharge. The earliest and lengthiest record in the Ivaí River is that of the Paraíso do Norte station which has been in operation since 1953 (20,228 days), while among the tributaries, the station of Patos River, the most upstream station, continuously operates since 1930 (28,520 days). The same performance cannot be obtained for suspended sediment, which data were predominantly recorded in the Ivaí River stations, being the Novo Porto Taquara station that consisted of the most extensive series of 157 measurements, (Figura 2, Table 2). 


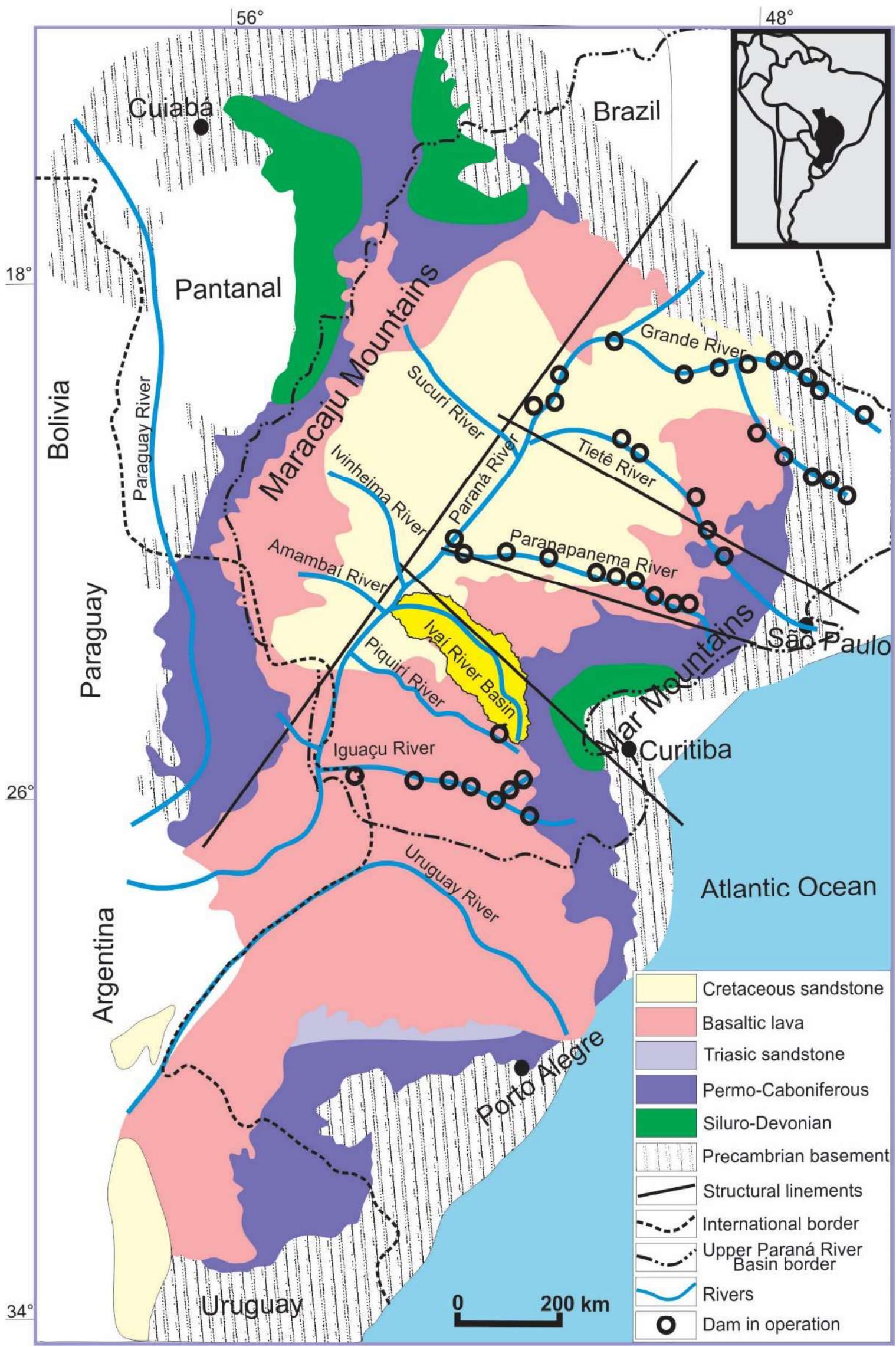

Figure 1 - Paraná Sedimentary Basin and main dams in the Upper Paraná River. Mod. (Stevaux \& Latrubesse, 2010). 
Table 1: Synthesis of physical characteristics of the Ivaí River Basin (Leli et al., 2011; Destefani, 2005; Andrade, 2003; Meurer, 2008; Bhering \& Santos, 2008).

\begin{tabular}{|c|c|c|c|c|}
\hline Sector basin & Lithology and soil & Relief & Vegetation & Climate \\
\hline $\begin{array}{l}\text { Upper: } \\
\text { Length: } 370 \mathrm{~km} \\
\text { Area: } 12,926 \mathrm{~km}^{2} \\
\text { Description: From } \\
\text { headwater to Alonso } \\
\text { River mouth. }\end{array}$ & $\begin{array}{l}\text { Shale, fine to very fine sandstone and limestone } \\
\text { of the Passa Dois Group (Permian) with diabase } \\
\text { sills and dikes. Eutrophic Regolithic Neosol, } \\
\text { Cambisol with } 0.5-1.3 \mathrm{~m} \text { in thickness, yellowish } \\
\text { red dystrophic Argisol and secondarily Red } \\
\text { Dystrophic Latosol, Red Dystroferric and } \\
\text { Eutroferric Latosol. }\end{array}$ & $\begin{array}{l}\text { From } 1,200 \text { to } 500 \mathrm{~m} \text {. } \\
\text { Very sculpted relief } \\
\text { with falls and rapids in } \\
\text { the main and tributary } \\
\text { rivers. }\end{array}$ & $\begin{array}{c}\text { Mixed } \\
\text { Ombrophilous } \\
\text { with Araucaria } \\
\text { Forest } \\
\text { Land use: natural } \\
\text { landscape. }\end{array}$ & $\begin{array}{l}\text { Subtropical } \\
\text { Annual } \\
\text { rainfall: } \\
2,000 \mathrm{~mm} \text {. }\end{array}$ \\
\hline $\begin{array}{l}\text { Middle: } \\
\text { Length: } 230 \mathrm{~km} \\
\text { Area: } 15,281 \mathrm{~km}^{2} \\
\text { Description: From } \\
\text { Alonso River to the } \\
\text { Porto Paraíso do Norte } \\
\text { gauging station. }\end{array}$ & $\begin{array}{c}\text { Basaltic traps and sandstone of São Bento } \\
\text { Group. Red Eutroferric Nitosol, Lithilic Neosol, } \\
\text { Red Dystrofferric and Eutroferric Latosol, Red } \\
\text { Dystrophic and Eutrophic Argisol. }\end{array}$ & $\begin{array}{l}\text { From } 500 \text { to } 300 \mathrm{~m} . \\
\text { Tabular relief with } \\
\text { mesetas, and demi- } \\
\text { orange mountains and } \\
\text { hills. River flow with } \\
\text { rapids and minor falls. }\end{array}$ & $\begin{array}{c}\text { Seasonal } \\
\text { semideciduous } \\
\text { Forest. } \\
\text { Land use: } 30- \\
\text { 40\% agriculture } \\
\text { and reforestation. }\end{array}$ & $\begin{array}{l}\text { Subtropical } \\
\text { Annual } \\
\text { rainfall } \\
1,700 \mathrm{~mm} \text {. }\end{array}$ \\
\hline $\begin{array}{l}\text { Lower: } \\
\text { Length: } 200 \mathrm{~km} \\
\text { Area: } 8,380 \mathrm{~km}^{2} \\
\text { Description: From } \\
\text { Porto Paraíso to its } \\
\text { mouth in the Paraná } \\
\text { River. }\end{array}$ & $\begin{array}{l}\text { Bauru Group sandstone, alluvium-colluvium } \\
\text { covering } \\
\text { Red Dystrophic Latosol, secondarily Yellowish } \\
\text { red Dystrophic Argisol and Fulvic Neosol. }\end{array}$ & $\begin{array}{l}\text { From } 300 \text { to } 230 \mathrm{~m} \text {. } \\
\text { Gentle hills, tranquil } \\
\text { flow with very scarce } \\
\text { rapids in main channel } \\
\text { and tributaries. }\end{array}$ & $\begin{array}{l}\text { Seasonal } \\
\text { semideciduous } \\
\text { Forest. } \\
\text { Land use: } 60- \\
70 \% \text { agriculture } \\
\text { and pasture. }\end{array}$ & $\begin{array}{l}\text { Tropical } \\
\text { Annual } \\
\text { rainfall } \\
1,400 \mathrm{~mm} \text {. }\end{array}$ \\
\hline
\end{tabular}

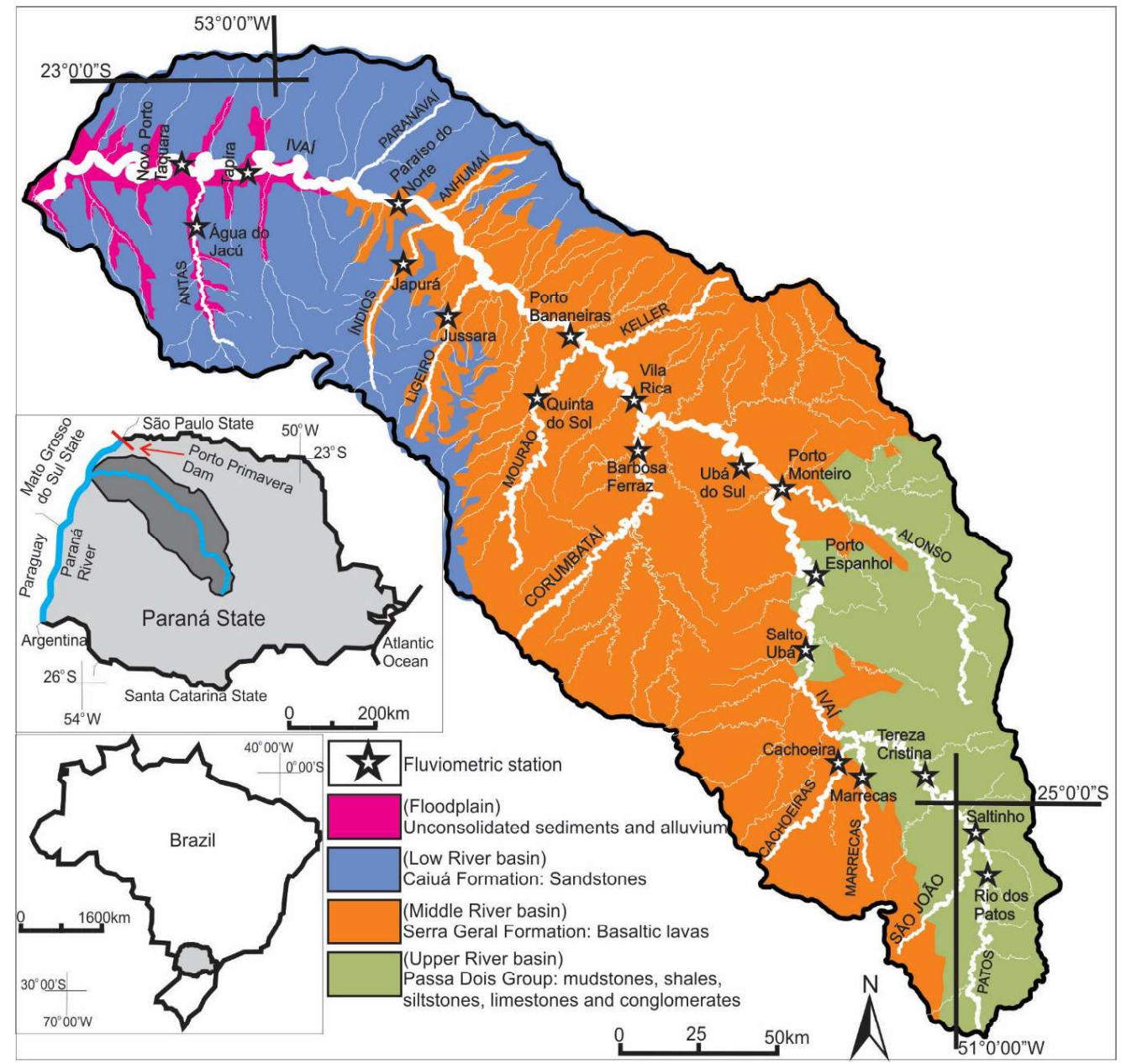

Figure 2 - Hydrographic map of the Ivai River Basin: its basin divisions and gauging stations. 
The parameters used for presenting this analysis includes historical series mean discharge (Qm), daily discharge $(\mathrm{Q})$, specific mean discharge (Qsp), mean discharge between stations ( $\mathrm{Qm} *$ ), mean suspended load concentration (Cssm), annual suspended load discharge (Qss), annual suspend load discharge between stations (Qss*), suspended sediment concentration between stations (Css*), specific suspended load discharge (Qsssp), whose definition and equation are presented in Table 3. In order to solve problems in gauging station distribution, a kind of regionalization was attempted (Table 4). The discharge of reaches or between tributaries $\left(\mathrm{Qm}^{*}\right)$ with no fluvial stations was obtained by grouping sub-basins as a unique tributary basin. In these cases, discharge was estimated by subtracting the discharge of upstream (Qm[us]) from downstream stations $(\mathrm{Qm}[\mathrm{ds}])$ according to the following equation:

$$
\text { Qm* }=\text { Qm[ds] - Qm[us] }
$$

The concentration of suspended sediment between stations $\left(\mathrm{Css}^{*}\right)$ was estimated using the annual suspended load between stations (Qss*) divided by annual water production of the reach $(\mathrm{Qm} * \mathrm{k})$ collected at 19 stations for water discharge and 13 stations for suspended sediment, as showed in the next equation:

$$
\mathrm{Css}^{*}=\mathrm{Qss} * /(\mathrm{Qm} * \mathrm{k})
$$

$\mathrm{k}$ is conversion factor (see table 3 ).

Table 2: Historical series for water and suspended sediment discharge and rainfall in gauging stations of the Ivaí River

\begin{tabular}{|c|c|c|c|c|c|c|c|}
\hline Stations(*) & River & $\begin{array}{c}\text { Days } \\
\text { for Qm }\end{array}$ & $\begin{array}{l}\text { Historical } \\
\text { series }\end{array}$ & $\begin{array}{l}\text { Days for } \\
\text { Css }\end{array}$ & $\begin{array}{c}\text { Historical } \\
\text { Series }\end{array}$ & $\begin{array}{c}\text { Days for } \\
\text { rainfall }\end{array}$ & $\begin{array}{c}\text { Historical } \\
\text { series }\end{array}$ \\
\hline Rio dos Patos & Patos & 28,502 & $\begin{array}{l}05 / 20 / 1930 \\
06 / 30 / 2008\end{array}$ & 30 & $\begin{array}{l}02 / 10 / 1982 \\
06 / 05 / 2008\end{array}$ & 7,066 & $\begin{array}{l}03 / 01 / 1937 \\
06 / 08 / 2008\end{array}$ \\
\hline Saltinho & São João & 670 & $\begin{array}{c}01 / 10 / 1955 \\
2 / 09 / 1956\end{array}$ & - & - & 2,660 & $\begin{array}{l}10 / 22 / 1975 \\
06 / 08 / 2008\end{array}$ \\
\hline Tereza Cristina & Ivaí & 18,890 & $\begin{array}{l}08 / 07 / 1956 \\
04 / 30 / 2008\end{array}$ & 84 & $\begin{array}{c}02 / 1 / 1982 \\
04 / 30 / 2008\end{array}$ & 6,463 & $\begin{array}{l}08 / 01 / 1956 \\
04 / 13 / 2008\end{array}$ \\
\hline Marrecas & Marrecas & 1,095 & $\begin{array}{l}09 / 02 / 2004 \\
12 / 09 / 2007\end{array}$ & - & - & - & - \\
\hline Cachoeira & Cachoeira & 2,555 & $\begin{array}{l}11 / 10 / 2000 \\
11 / 09 / 2007\end{array}$ & - & - & - & - \\
\hline Salto Ubá & Ivaí & 4,015 & $\begin{array}{l}05 / 11 / 1949 \\
05 / 08 / 1960\end{array}$ & - & - & 103 & $\begin{array}{l}01 / 01 / 1956 \\
12 / 31 / 1956\end{array}$ \\
\hline Porto Espanhol & Ivaí & 15,695 & $\begin{array}{l}08 / 13 / 1965 \\
05 / 10 / 2008\end{array}$ & - & - & 4,214 & $\begin{array}{l}08 / 10 / 1965 \\
06 / 08 / 2008\end{array}$ \\
\hline Porto Monteiro & Alonso & 12,410 & $\begin{array}{l}01 / 29 / 1974 \\
07 / 08 / 2008\end{array}$ & - & - & 2,767 & $\begin{array}{l}01 / 01 / 1974 \\
06 / 08 / 2008\end{array}$ \\
\hline Uba do Sul & Ivaí & 15,150 & $\begin{array}{l}04 / 16 / 1967 \\
06 / 05 / 2008\end{array}$ & 95 & $\begin{array}{c}0116 / 1982 \\
06 / 05 / 2008\end{array}$ & 3,874 & $\begin{array}{l}04 / 01 / 1967 \\
06 / 08 / 2008\end{array}$ \\
\hline Barbosa Ferraz & Corumbataí & 12,385 & $\begin{array}{l}08 / 19 / 1974 \\
07 / 16 / 2008\end{array}$ & 79 & $\begin{array}{l}01 / 18 / 1982 \\
11 / 21 / 2007\end{array}$ & 3,118 & $\begin{array}{l}08 / 01 / 1974 \\
06 / 08 / 2008\end{array}$ \\
\hline Vila Rica & Ivaí & 8,360 & $\begin{array}{l}08 / 14 / 1985 \\
06 / 05 / 2008\end{array}$ & 76 & $\begin{array}{l}11 / 06 / 1990 \\
06 / 05 / 2008\end{array}$ & 1,963 & $\begin{array}{l}09 / 14 / 1985 \\
11 / 10 / 2007\end{array}$ \\
\hline Quinta do Sol & Mourão & 12,392 & $\begin{array}{l}08 / 08 / 1974 \\
06 / 05 / 2008\end{array}$ & 132 & $\begin{array}{l}04 / 18 / 1977 \\
06 / 05 / 2008\end{array}$ & 2,775 & $\begin{array}{l}08 / 01 / 1974 \\
06 / 05 / 2008\end{array}$ \\
\hline Porto Bananeiras & Ivaí & 12,510 & $\begin{array}{l}02 / 19 / 1974 \\
06 / 05 / 2008\end{array}$ & 59 & $\begin{array}{l}09 / 16 / 1980 \\
06 / 07 / 2008\end{array}$ & 3,394 & $\begin{array}{l}02 / 19 / 1974 \\
06 / 05 / 2008\end{array}$ \\
\hline Jussara & Ligeiro & 56 & $\begin{array}{l}01 / 24 / 1982 \\
06 / 06 / 2008\end{array}$ & 56 & $\begin{array}{l}01 / 24 / 1982 \\
06 / 06 / 2008\end{array}$ & 1,633 & $\begin{array}{l}01 / 22 / 1975 \\
12 / 31 / 1997\end{array}$ \\
\hline Japurá & Índios & 11,06 & $\begin{array}{l}01 / 01 / 1977 \\
06 / 05 / 2008 \\
\end{array}$ & 83 & $\begin{array}{l}01 / 25 / 1982 \\
06 / 06 / 2008\end{array}$ & 2,851 & $\begin{array}{l}12 / 16 / 1975 \\
06 / 05 / 2008\end{array}$ \\
\hline Paraíso do Norte & Ivaí & 20,226 & $\begin{array}{l}05 / 23 / 1953 \\
07 / 29 / 2008\end{array}$ & 95 & $\begin{array}{l}04 / 16 / 1977 \\
06 / 04 / 2008\end{array}$ & 664 & $\begin{array}{l}05 / 23 / 1953 \\
06 / 05 / 2008\end{array}$ \\
\hline Tapira & Ivaí & 5,110 & $\begin{array}{l}10 / 24 / 1976 \\
07 / 31 / 1990\end{array}$ & 50 & - & 2,970 & $\begin{array}{l}12 / 16 / 1975 \\
06 / 05 / 2008\end{array}$ \\
\hline Água do Jacu & Antas & 1,625 & $\begin{array}{l}06 / 04 / 1977 \\
03 / 01 / 1991\end{array}$ & 47 & $\begin{array}{l}08 / 12 / 1979 \\
08 / 30 / 1989\end{array}$ & 2,045 & $\begin{array}{l}01 / 06 / 1978 \\
05 / 16 / 2001\end{array}$ \\
\hline Novo Porto Taquara & Ivaí & 12,210 & $\begin{array}{l}01 / 07 / 1974 \\
06 / 05 / 2008\end{array}$ & 157 & $\begin{array}{l}09 / 14 / 1974 \\
06 / 05 / 2008\end{array}$ & 2,589 & $\begin{array}{l}07 / 01 / 1974 \\
06 / 05 / 2008\end{array}$ \\
\hline
\end{tabular}
Basin (Source: SUDHERSA).

(*) Bold letters represent stations in the Ivai River. 
The three main stations that gauge the major sectors (and their respective gauging period) of the Ivai Basin the Ubá do Sul in the upper, (1982-2008), Paraíso do Norte in the middle (1977-2008), and Novo Porto Taquara in the lower (1974-2008) (Figura 2).

Table 3: Definition of hydrosedimentological variables.

\begin{tabular}{|c|c|c|}
\hline Variable & Definition & Unit \\
\hline Historical series mean discharge $(\mathrm{Qm})$ & & $m^{3} s^{-1}$ \\
\hline Specific discharge (Qsp) & $Q s p=Q m / A b$ & $m^{3} s^{-1} k^{-2}$ \\
\hline Mean suspended load concentration (Cssm) & & $m g L^{-1}$ \\
\hline Annual suspended load discharge (Qss) & $Q s s=C s m \cdot Q m \cdot k \cdot 10^{-6}$ & tyear ${ }^{-1}$ \\
\hline Annual suspended load discharge between stations (Qss $\left.{ }^{*}\right)$ & $Q s s^{*}=Q s s[d s]-Q s s[u s]$ & t year $^{-1}$ \\
\hline Mean water discharge between stations (Qm*) & $Q m *=Q m[d s]-Q m[u s]$ & $m^{3} s^{-1}$ \\
\hline Suspended sediment concentration between stations (Css $\left.{ }^{*}\right)$ & $C s s^{*}=Q s s^{*} /(Q m * k)$ & $m g L^{-1}$ \\
\hline Specific suspended load discharge (Qsssp) & $Q s s s p=Q s s / A b$ & tyear-1 $\mathrm{km}^{-2}$ \\
\hline
\end{tabular}

$Q=$ daily discharge, $A b=$ basin area, Css $=$ daily suspended load concentration, $n=$ number of days of historical series, [ds] and [us] $=$ down and upstream, $k=$ unit conversion factor $=31,536(60 \mathrm{seg} \times 60 \mathrm{~min} \times 24 \mathrm{~h} \times 365$ days $)$.

\section{Results}

In spite of the small number of gauging stations and their irregular distribution over the drainage basin (Figura 2), the relatively long historical series for water and suspended load discharge (Table 2), and the uniformity in the basin's elongated morphology (compaction coefficient $=2.46$; form factor $=0.06$ ), with regular joining of tributaries, contributed towards a good cor- relation between the hydrosedimentologic parameters and the spatial distribution of load suspension dynamics in the basin.

Over a 34-year historical series (1974-2008), the Ivaí River has a mean discharge of $702.9 \mathrm{~m}^{3} \cdot \mathrm{s}^{-1}$, corresponding to a $64 \%$ permanence, measured at its lowest gauging station (Novo Porto Taquara), and a mean flood discharge of $4,019 \mathrm{~m}^{3} \mathrm{~s}^{-1}$ with a permanence of $1 \%$ (Figura 3 ).

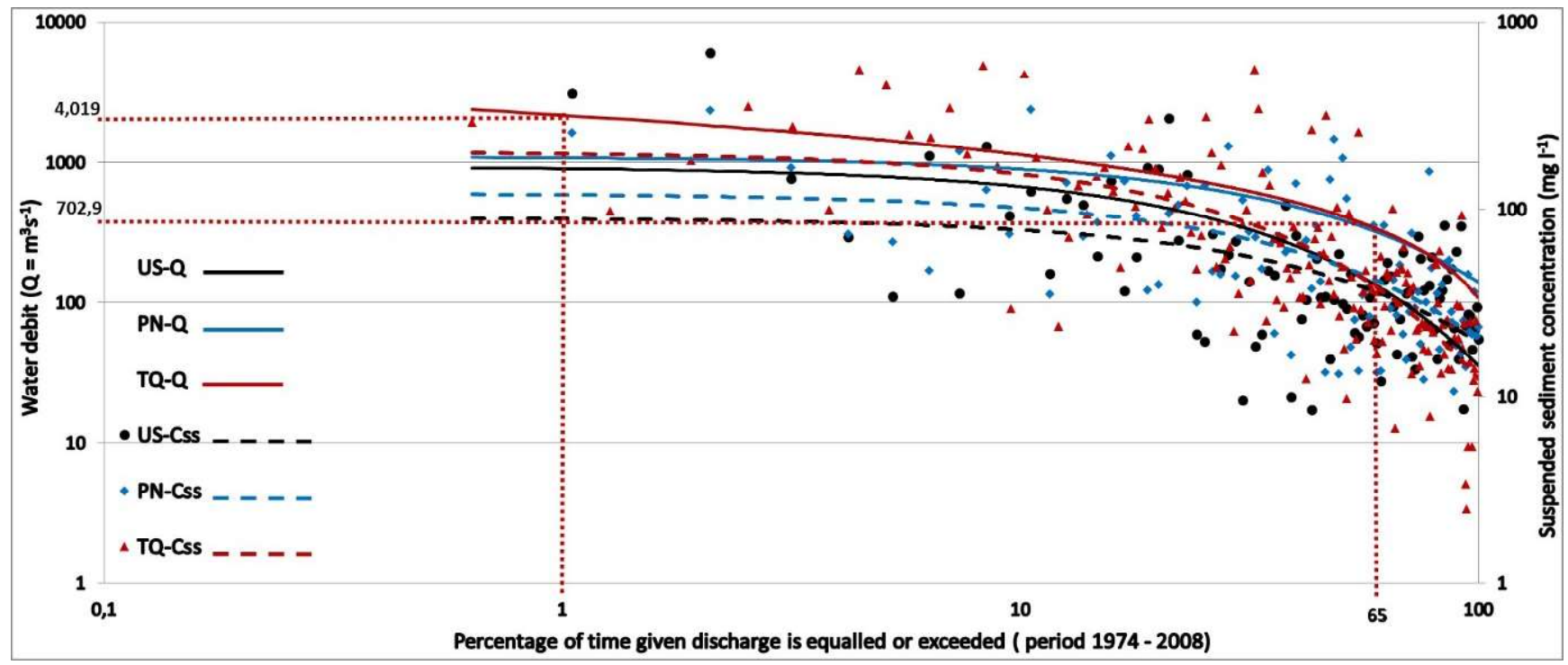

Figure 3 - Percentage of time to a given water discharge (Q) and suspended sediment concentration (Css) at Ubá do Sul (US), Paraíso do Norte (PN) and Novo Porto Taquara (TQ) gauging stations. Red dotted line shows the percentage of time of mean (65\%) and mean flood discharges (1\%) at TQ. 
According to Paiva (2008), base flow cannot maintain river flow near mean discharge, so, the Ivaí River hydrological regime is controlled by surface runoff. The largest discharge recorded in the historical series is $5,800 \mathrm{~m}^{3} \mathrm{~s}^{-1}$ in 1992 with a recurrence of 23 years (DESTEFANI, 2005). The river hydrograph is characterized by significant discharge variability with abrupt changes in magnitude (Figura 4). Flood peaks do not follow a seasonal pattern, occurring in any month of the year, and may change from one year to another because of the action of cold front rains and orographic precipitation (ANDRADE, 2003). Data of water and suspended sediments for the Ivaí and tributaries are synthetized on table 4 .

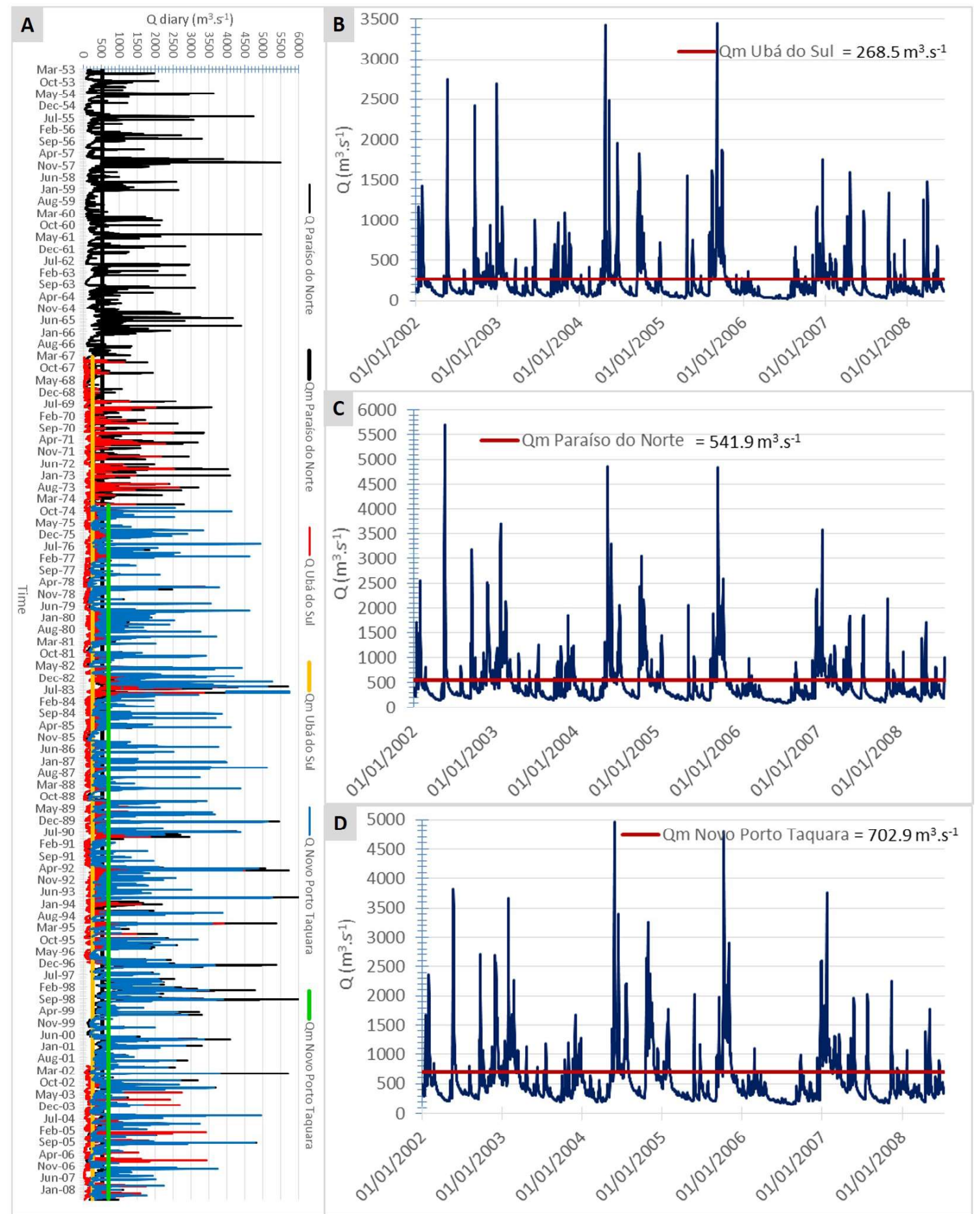

Figure 4 - Hydrograph of the Ivai River at the principal gauging stations. A: Total historical series hydrograph, Paraíso do Norte (1953), Ubá do Sul (1967), Novo Porto Taquara (1974). B, C, D: detailed hydrograph for these gauging stations 
Table 4: Synthesis of results for water and suspended sediment in the Ivaí River, tributaries, gauging Stations, and reaches between gauging stations.

\begin{tabular}{|c|c|c|c|c|c|c|c|c|c|}
\hline 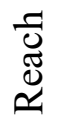 & $\begin{array}{l}\text { Subasin } \\
\text { reach }\end{array}$ & $\begin{array}{l}\mathrm{Qm} \\
\mathrm{ms}^{-1}\end{array}$ & $\begin{array}{c}\mathrm{Ac} \\
\mathrm{Qm} \mathrm{m}^{3} \mathrm{~s}^{-1}\end{array}$ & $\begin{array}{c}\mathrm{A} \\
\mathrm{km}^{2}\end{array}$ & $\begin{array}{l}\mathrm{AcA} \\
\mathrm{km}^{2}\end{array}$ & $\begin{array}{c}\text { Qmsp } \\
\mathrm{m}^{3} \mathrm{~s}^{-1} \mathrm{~km}^{-2}\end{array}$ & $\begin{array}{l}\text { Css } \\
\mathrm{mg} \mathrm{L}^{-1}\end{array}$ & $\begin{array}{c}\text { Qss } \\
\text { ty }^{-1}\left(\text { ton } y^{-1}\right)\end{array}$ & $\begin{array}{l}\text { Qsssp } \\
\text { ty }^{-1} \mathrm{~km}^{-2}\end{array}$ \\
\hline \multirow{12}{*}{$\begin{array}{l}\grave{D} \\
\stackrel{2}{D}\end{array}$} & Patos (PA) & 22.4 & & 1,086 & & 0.022 & 49.86 & $35,221.4$ & 32.43 \\
\hline & São João (SJ) & 14 & & 560 & & 0.025 & & & \\
\hline & *PA/SJ-TC & 39 & & 1,926 & & 0.02 & 63 & $77,020.9$ & 40 \\
\hline & Tereza Cristina (TC) & & 75.4 & & 3,572 & 0.02 & $\mathbf{5 7 . 5 6}$ & 136,867 & 38.8 \\
\hline & Marrecas + Cachoeira & 19.2 & & 698 & & 0.027 & & & \\
\hline & *TC-SU & 28.4 & & 3,733 & & 0.008 & 60 & $366,322.2$ & 40.13 \\
\hline & Salto Ubá (SU) & & 123 & & 8,003 & 0.015 & & & \\
\hline & *SU-PE & 68 & & 597 & & 0.113 & & & \\
\hline & Porto Espanhol (PE) & & 191 & & 8,600 & 0.022 & & & \\
\hline & *PE-US & & & 1,481 & & & & & \\
\hline & Foz do Rio Alonso & 51 & & 2,620 & & 0.019 & & & \\
\hline & Ubá do Sul (US) & & 269 & & 12,701 & 0.018 & 63.49 & $538,597.4$ & 42.4 \\
\hline \multirow{10}{*}{$\begin{array}{l}\frac{0}{7} \\
\frac{\pi}{2}\end{array}$} & *US-VR & 79. & & 3,305 & & 0.024 & 51.6 & $130,131.8$ & 39.37 \\
\hline & Bacia Corumbataí & 74.6 & & 3,294 & & 0.023 & 41.44 & 97,491 & 29.6 \\
\hline & Vila Rica (VR) & & 423.3 & & 19,300 & 0.023 & 49.92 & $666,391.5$ & 34.52 \\
\hline & *VR-PB & 38.8 & & 2,273 & & 0.017 & 58.53 & $71,617.1$ & 31.51 \\
\hline & Rio Mourão & 32.6 & & 1,534 & & 0.021 & 44.55 & $45,800.7$ & 29.85 \\
\hline & Porto Bananeira (PB) & & 494.7 & & 23,107 & 0.021 & 81.12 & $1,265,541.7$ & 54.8 \\
\hline & *PB-PN & 23.9 & & 3,786 & & 0.006 & 66.6 & $39,695.6$ & 10.48 \\
\hline & Bacia do Índio & 14,6 & & 807 & & 0.018 & 38.64 & $17,790.8$ & 22.04 \\
\hline & Bacia do Ligeiro & 14,8 & & 727 & & 0.02 & 75.39 & 35,187 & 48.4 \\
\hline & Paraíso do Norte (PN) & & 543 & & 28,427 & 0.019 & 71.27 & $1,220,430$ & 42.93 \\
\hline \multirow{7}{*}{$\stackrel{\dot{0}}{\stackrel{0}{0}}$} & *PN-TP & 68.3 & & 3,528 & & 0.019 & 54.21 & $116,763.4$ & 33.1 \\
\hline & Tapira (TP) & & 611.3 & & 31,955 & 0.019 & 37.15 & $1,373,940$ & 43 \\
\hline & *TP-TQ & 75.2 & & 1497 & & 0.05 & 65.7 & 155808 & 104.08 \\
\hline & Bacia Rio Das Antas & $14 ., 5$ & & 980 & & 0.015 & 69 & 31551.8 & 32.2 \\
\hline & $\begin{array}{c}\text { Novo Porto Taquara } \\
\text { (TQ) }\end{array}$ & & 701 & & 34,432 & 0.02 & 90.68 & $2,004,638.8$ & 58.22 \\
\hline & *TQ-FI & 32.4 & & 2155 & & 0.015 & 90.68 & $92,653.7$ & 43 \\
\hline & Foz do Ivaí (FI) & & 733.4 & & 36,587 & 0.02 & 90.68 & $2,097,292.6$ & 57.32 \\
\hline
\end{tabular}

Bold letters represent stations in the Ivai River; (*) reaches between gauging stations, AcQm and AcA = accumulate mean discharge and accumulate basin area.

\subsection{Spatial distribution of discharges}

The increase in discharge of water is progressively constant along the river (Figura $5 \mathrm{~A}$ ), generating a high correlation $\left(\mathrm{R}^{2}=0.99\right)$ among drainage area and discharge (Figura 5 B). This is directly related with the basin's elongation and tributary drainage distribution.
Sub-basins are similar in shape and size, are subjected to the same climate, and therefore, provide similar discharges to the trunk river.

The main tributaries of the Ivaí River are the Alonso River $\left(\mathrm{Qm}=51.0 \mathrm{~m}^{3} \mathrm{~s}^{-1}\right)$ on the right-hand side, and the Corumbataí and Mourão (sum total Qm $=107.2$ 
$\mathrm{m}^{3} \mathrm{~s}^{-1}$ ) on the left-hand side (Figura $5 \mathrm{~A}, \mathrm{C}$ ). However, the majority of the water that enters the main channel comes from smaller tributaries (basin area $<500 \mathrm{~km}^{2}$ ) that contribute $387.3 \mathrm{~m}^{3} \mathrm{~s}^{-1}$, that is, $53 \%$ of the Ivaí River's average discharge (Figura $5 \mathrm{C}$ ). The contribution of these tributary basins is quite varied along the Ivaí (Figura $5 \mathrm{~B}$ ). The highest contributions observed came from the drainages between the Ubá do Sul and Vila Rica gauging stations $\left(\mathrm{Qm} 79.0 \mathrm{~m}^{3} \mathrm{~s}^{-1}\right)$ in the high and middle reach limits, and between the Paraíso do Norte and Tapira gauging stations $\left(\mathrm{Qm} 68.3 \mathrm{~m}^{3} \mathrm{~s}^{-1}\right)$ in the lower reach (Figura $5 \mathrm{C}$ ).
If the correlation of $\mathrm{Qm}$ versus basin area is high, the flood discharge shows an anomaly when plotted with area in the last two stations (Figura 6A). Destefani (2005) analyzed the 1992 flood and showed that above $4,000 \mathrm{~m}^{3} \mathrm{~s}^{-1}$, the river lost water to the floodplain downstream of the Paraíso do Norte Gauge Station (Figura 6B). It can also be observed that when this threshold flood discharge $\left(4,000 \mathrm{~m}^{3} \mathrm{~s}^{-1}\right)$ is reached, Novo Porto Taquara station presents discharge lower than the four upstream gauge stations. In this flood, an estimated volume of $200 \times 10^{7} \mathrm{~m}^{3}$ of water was diverted to the floodplain in 5 days.

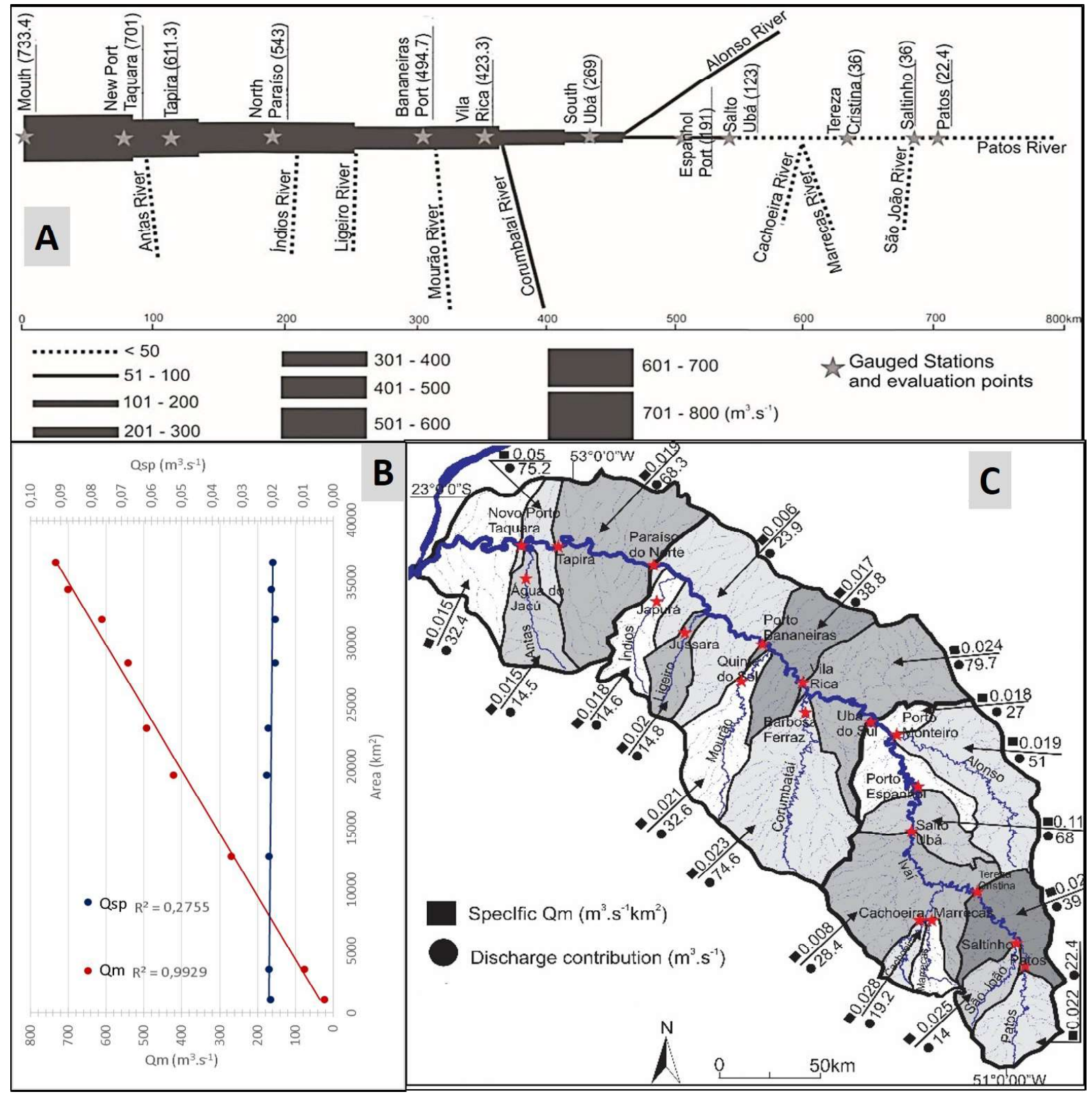

Figure 5 - A. Drainage tree for discharge in the Ivai River Basin, the main water contribution. B. The mean discharge and basin area present strong correlation, and the specific discharge is relatively constant along the basin. C. Ivai River Basin with main tributary basins and small basin groups, (Source: Table 4). 
The specific discharge is relatively constant along the basin (Figura 5 B). The largest tributary basins that feed the Ivaí present specific discharges between 0.019 and $0.023 \mathrm{~m}^{3} \mathrm{~s}^{-1} \mathrm{~km}^{-2}$ as the Corumbataí and Alonso Rivers. The largest specific discharges (Marrecas-Cachoeira $=0.028 \mathrm{~m}^{3} \mathrm{~s}^{-1} \mathrm{~km}^{-2}$ and São João $=0.02 \mathrm{~m}^{3}$ $\mathrm{s}^{-1} \mathrm{~km}^{-2}$ ) are in the upper reach, where the orographic precipitation is more significant. In general, the specific discharge varies from 0.019 to $0.20 \mathrm{~m}^{3} \mathrm{~s}^{-1} \mathrm{~km}^{-2}$ for basins in the upper reach, and from 0.015 to $0.020 \mathrm{~m}^{3} \mathrm{~s}^{-1} \mathrm{~km}^{-2}$ for basins in the lower reach.

Unlike the values for contribution of discharge, the specific discharge for the smallest basins, when taken together, present lower values than the main tributaries. These values, in general, do not exceed $0.020 \mathrm{~m}^{3} \mathrm{~s}^{-1}$ $\mathrm{km}^{-2}$. However, some anomalies are found. Between Salto Ubá and Porto Espanhol gauging stations, a reach of only $30 \mathrm{~km}$ contributes $65 \mathrm{~m}^{3} \mathrm{~s}^{-1}$ to the Ivaí medium discharge, which corresponds to a specific discharge of $0.11 \mathrm{~m}^{3} \mathrm{~s}^{-1} \mathrm{~km}^{-2}, 10$ times larger than the other tributary basins (Figura 5 C). Paiva (2008) suggests that some sub-basins have strongly influenced groundwater contribution in discharge owing to local distribution and the concentration of basalt fractures.

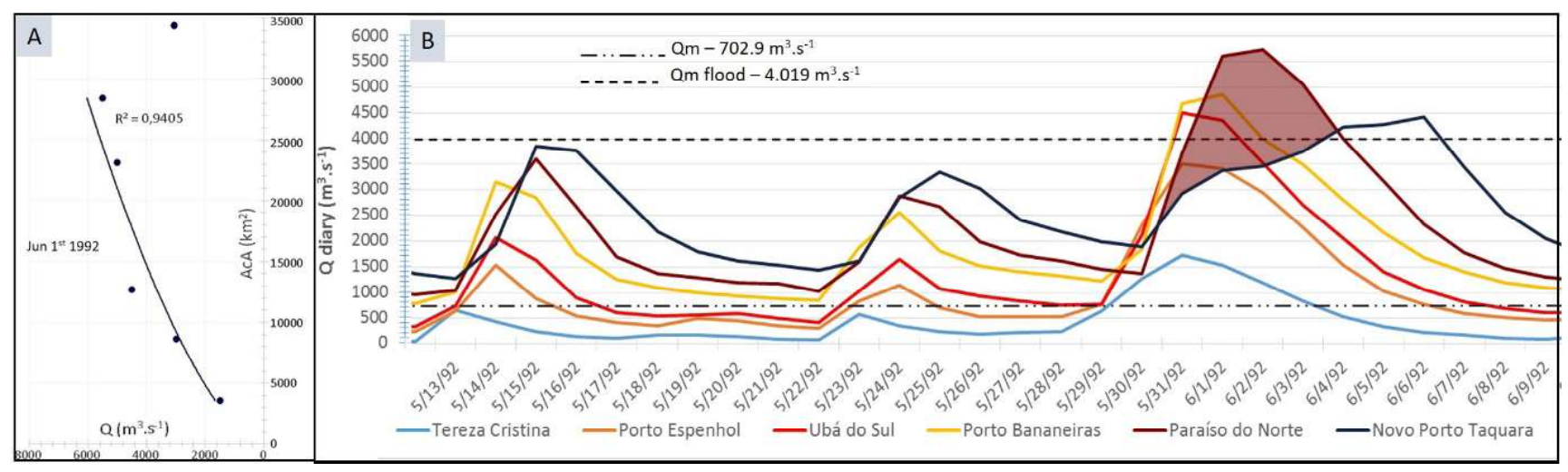

Figure 6 - A. Mean flood discharge versus basin area. Note that the last two stations (corresponding to two largest basin areas) present lower discharge values than the upstream station. B. Hydrograph of the Ivai River gauging stations. Three flood peaks are observed between May 21 and June 10, 1992. There is a normal increase in water discharge in the downstream direction in the first and second peaks. In the third peak, the volume in the Paraiso do Norte is greater than in the downstream station of Novo Porto Taquara, thus showing water lost to the floodplain downstream of Paraiso do Norte. The shaded area in the hydrograph curves corresponds to the volume of water diverted to the floodplain $(\sim 200 \times 107 \mathrm{m3})$. (Mod. DESTEFANI, 2005).

\subsection{Formation of the suspended load}

The correlation of suspended load concentration and discharge is very dispersive to the Ivaí River. However, small variations can be observed during the year. Agriculture seasonality is the major controlling factor for concentration of suspended sediment. The combination between soil preparation, planting and high rainfall from September to March, produce a more dispersive correlation between water discharge and concentration of suspended load than in the April to August period, when soil is covered (Figura 7 A). Leli et al., (2011) pointed out that agricultural seasonality associated with basin morphology and valley slope, are responsible for the clockwork hysteresis diagram of concentration versus discharge (Figura $7 \mathrm{~B}$ ). A more suitable agricultural management in the basin, implemented by the state government, reduced laminar erosion caused by the rain, thus reflecting the rate of reduction of sediment production for the river (Figura $7 \mathrm{C}$ ).

In spite of low correlation between concentration of suspended sediment and water discharge (Figura 7A), the annual transport of suspended sediment calculated for all stations during the historical series presented high correlation $\left(\mathrm{R}^{2}=0.97\right)$ in respect of both water discharge and basin area (Figura 8 ). The basin asymmetry related to the trunk river, slightly shifted to the right-hand side, generates larger basins on the left-hand side. This fact controls the spatial distribution for suspended load. The largest contribution of suspended load comes from the main tributaries on the left side of the medium reach: Corumbataí, Mourão, and the Ligeiro Rivers that add up to $17.8 \times 10^{4}$ ton year $^{-1}$, and the Antas River (Qss $=31.5$ $\times 10^{3}$ ton year ${ }^{-1}$ ) of the lower reach. The Patos, one of the 
Ivaí-forming rivers, also presents a high contribution of $35.2 \times 10^{3}$ ton year $^{-1}$ (Figura 9A, B). The Alonso River, the main right-hand tributary of the Ivaí does not have a gauging station for suspended sediment. The huge production of $366.3 \times 10^{3}$ ton year $^{-1}$ (Figura $9 \mathrm{~B}$ ), estimated for an area of $9,121 \mathrm{~km}^{2}$, is not related only to the Alonso River, but to a group of tributary basins including the Marrecas and Cachoeira Rivers, that also do not have a suspended sediment gauging station. The annual production of suspended sediment of $96.5 \times 10^{3}$ ton year ${ }^{-1}$ estimated for the Alonso River is inferred from the average suspended concentration for the reach of $60 \mathrm{mg} \mathrm{L}^{-1}$.

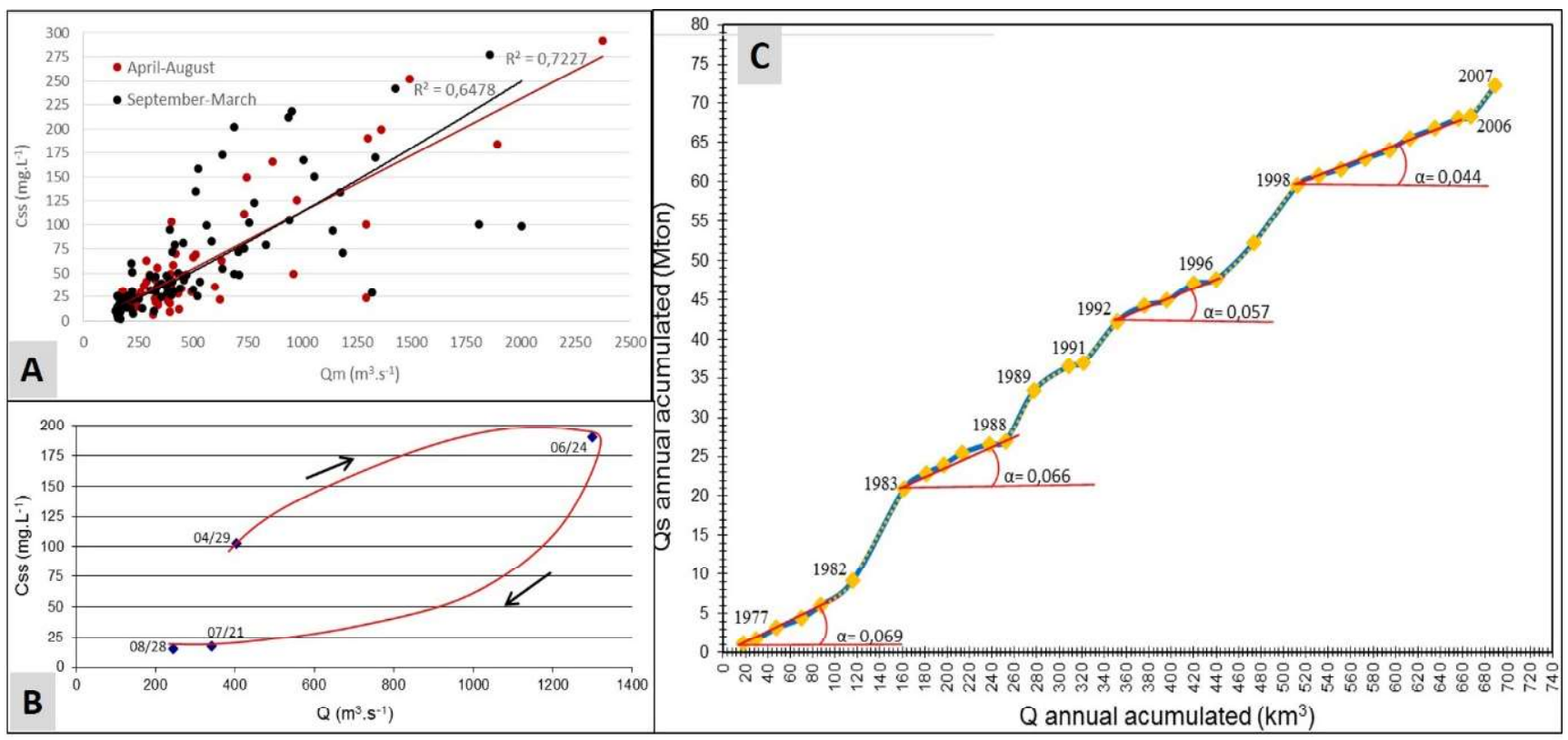

Figure 7 - Correlation between concentration of suspended sediment versus water discharge in the dry April-August, and rainy SeptemberMarch (A) periods. Clockwork hysteresis diagram (B) for concentration of suspended sediment and water discharge average during the 1977 flood. (C) Reduction in the sediment production rate ( $\alpha$ ) since the end of the 1970s, by a more accurate agricultural land use (Mod. Leli et al., 2011).
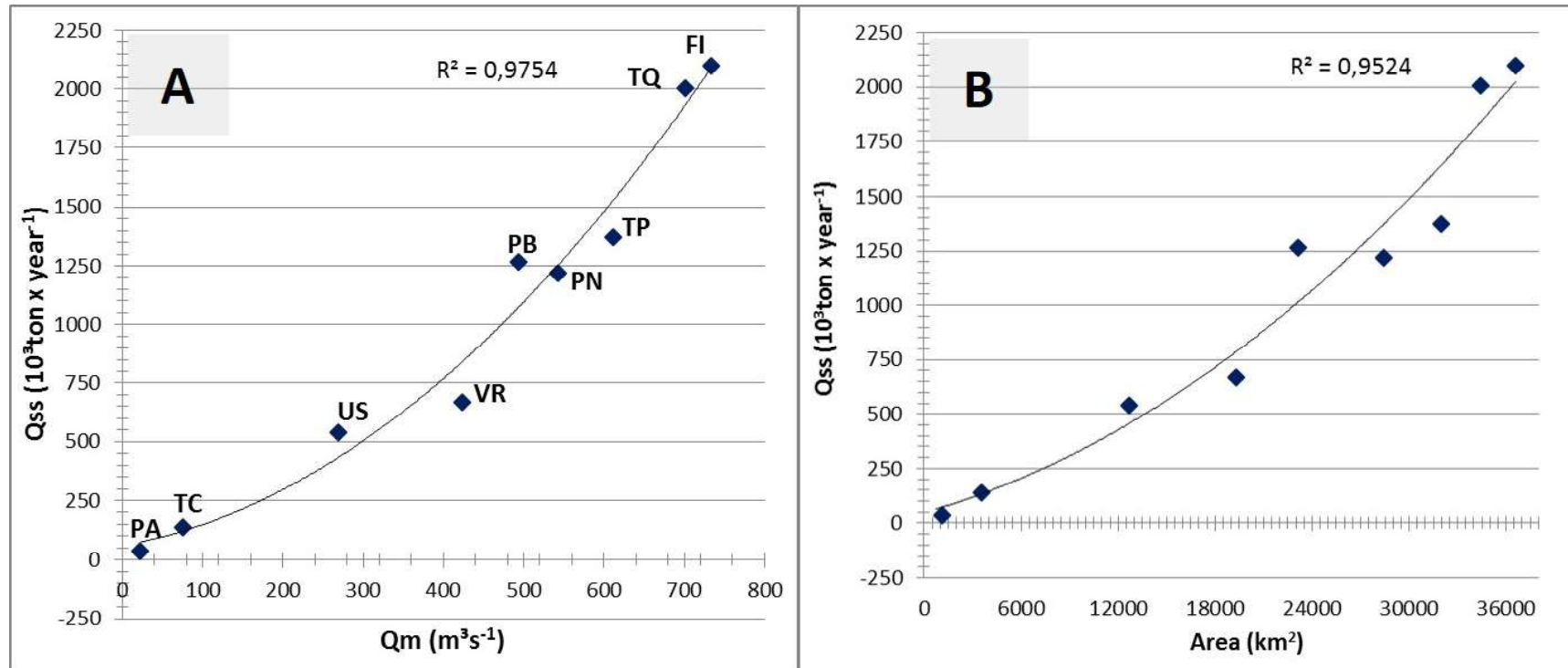

Figure 8 - Correlation $(p<0.005)$ between annual discharge of suspended sediment (Qss) vs. mean water discharge $(Q m)$ in A and basin area in B in the gauging stations of the Ivai River: PA - Rio dos Patos, TC - Tereza Cristina, US - Ubá do Sul, VR - Vila Rica, PB - Porto Bananeira, PN-Paraíso do Norte, TP - Tapira, TQ - Novo Porto Taquara, FI-Ivai River mouth (Data source: Table 4). 
The input of the suspended load along the Ivai River's longitudinal profile takes place gradually, thus implying a homogeneous intake of suspended sediment into the channel (Figura 9 A). The specific suspended load discharge for tributary basins is not homogenous, but increases slightly downstream (Figura 9 B, C) even with the specific water discharge staying constant (see Figura 5 D). The intensive land use of the lower Ivaí River Basin, predominantly with agriculture and pasture, increases sedimentary yield, enhanced by the highly erosive sandy soil derived from the Caiuá Formation. In addition, in its lower basin, the Ivaí has a 20 $\mathrm{km}$ wide floodplain (Figura 2) with intensive farming occupations, especially for rice, soybean, and pasture, which enhance transport of sediment to the channel. On the other hand, the almost $200 \times 10^{7} \mathrm{~m}^{3}$ of water loss observed during the 1992 great flood between Paraíso and Novo Porto Taquara gauging stations (Figura 6), also transferred about 500,000 tons of sediment to the floodplain.

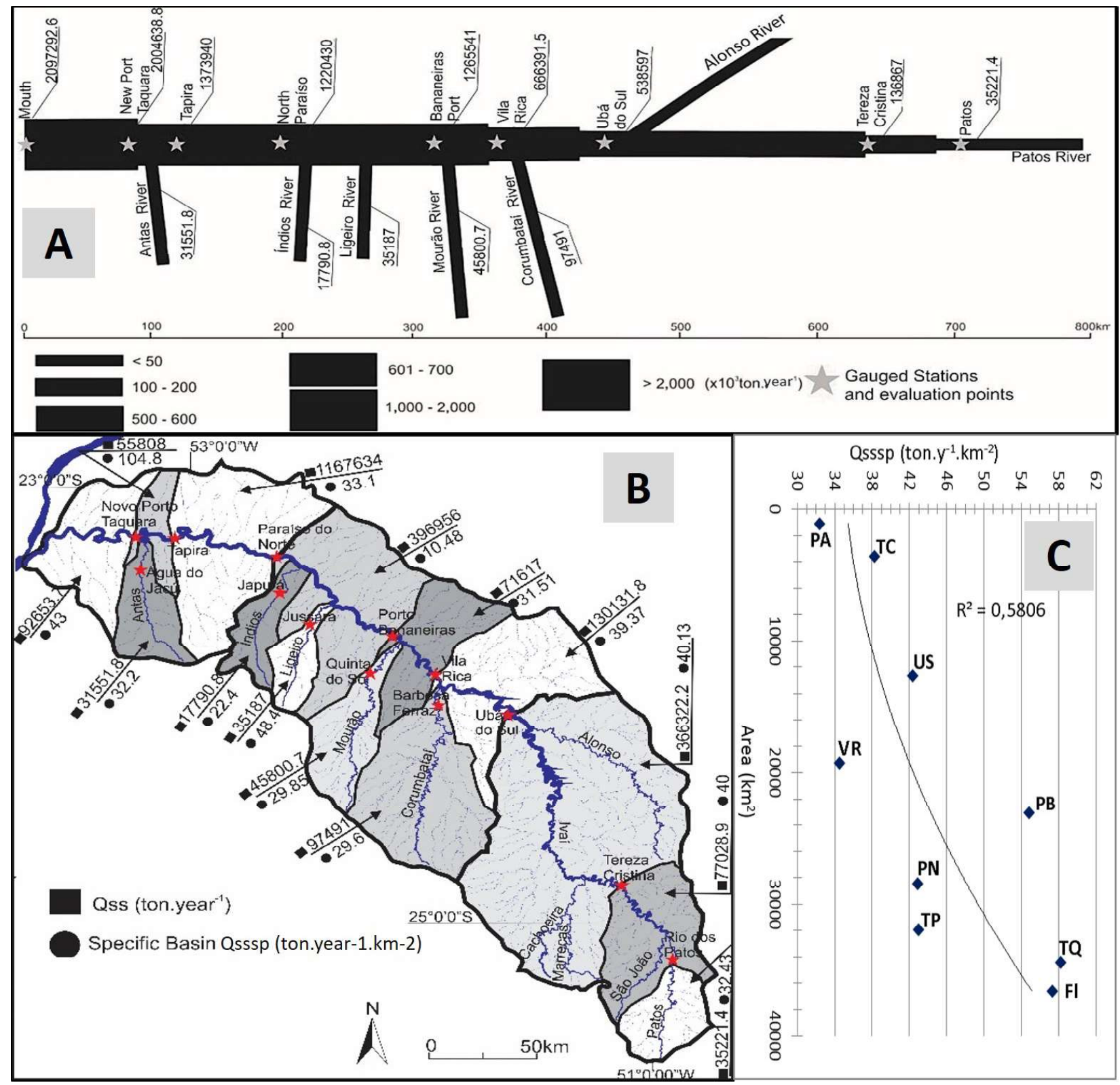

Figure 9 - A. The Ivai River Basin drainage tree for the annual suspended sediment discharge. B. Annual suspended load and specific discharge for tributary basins and group of basins. C. Correlation between specific suspended sediment discharge versus basin area. The correlation is weak; however, the downstream increase of values to the last gauging stations is evident. 


\section{Discussion}

As mentioned earlier, the Ivaí is one of the unique medium tributaries of the Paraná Basin, and is in a natural condition concerning its flow regime, and therefore, should be considered as a model for this type of river for future projects on river restoration and management. In Brazil, where studies concerning impact mitigation, management and restoration were normally made after dam construction, the present study of this river can be considered as a laboratory for fluvial investigation, and efforts should be made with the aim to preserve this system from hydroelectric power stations.

Latrubesse et al., (2005) classified the tropical rivers in the world based on a geological-geomorphologic setting and climate zone. Under these criteria, the Ivaí is classified as platform/plateau river draining dominantly platform areas, bedrock channels, with incised valleys and rapids under wet-dry climate. In spite of the referred paper using only large rivers $\left(\mathrm{Qm}>4000 \mathrm{~m}^{3} \mathrm{~s}^{-1}\right)$, the Ivaí presents the same characteristics as those of large rivers, when compared under these criteria. Concerning maximum $\left(\mathrm{Q}_{\max }\right)$, minimum $\left(\mathrm{Q}_{\text {min }}\right)$ and medium $\left(\mathrm{Q}_{\text {mean }}\right)$ water discharge, the Ivaí can be clubbed along with the rivers in dry-wet and temperate climates (Figura $10 \mathrm{~A}$ ).

With most of the basin located south of the Tropic of Capricorn, the Ivaí River is under the influence of two types of climate. While its lower basin presents a wet-dry tropical climate with a dry winter and a rainy summer, the central and upper basins are under the influence of a temperate climate, with rainfall of $1800 \mathrm{~mm}$, with strong orographic influence (Caramori, 1989; IAP, 1994; Brasil, 1985). This fact justifies grouping of the Ivaí with temperate and wet-dry climate rivers (Figura $10 \mathrm{~A}$ ). The same high correlation can be seen when plotting the Ivaí River in terms of annual suspended load discharge versus basin area for plateau-cratonic rivers (Figura $10 \mathrm{~B}$ ). In this correlation, the Ivaí lines up with the Araguaia, Paraná, Sanaga (Cameroon), Zambesi (SW Africa), Tocantins, and Xingu Rivers (Latrubesse et al., 2005).

Leli et al., (2011) concluded that sediment yield to the Ivaí River had decreased in the last two decades, due to more suitable land use management in terms of agriculture and pasture. However, when the values of sediment yield of the Ivaí River are compared with those from the Araguaia River, the large Brazilian river most impacted by agricultural and pasture (Latrubesse and Stevaux, 1999; Latrubesse et al., 2009), it is possible to assume that the situation in the river under study is very delicate in terms of human impact (Table 1,5). Unlike the Araguaia River, the Ivaí is a suspended-load-dominant river, and the possible impacts will not be in the channel morphology like the Araguaia, but, in changes to the water quality and river ecology. Evidences of impact of agriculture and pasture on sediment yield of the Ivaí could be related with the anomalous values in the concentration of suspended sediment obtained in some gauging stations. Concentrations between 300 and $600 \mathrm{mg} \mathrm{L}^{-1}$ were observed in Novo Porto Taquara gauging station 11 times in the historical series. Such occurrences, though not very frequent, may be signaling impacts due to wrong procedures in the basin, especially in the floodplain of its lower basin.

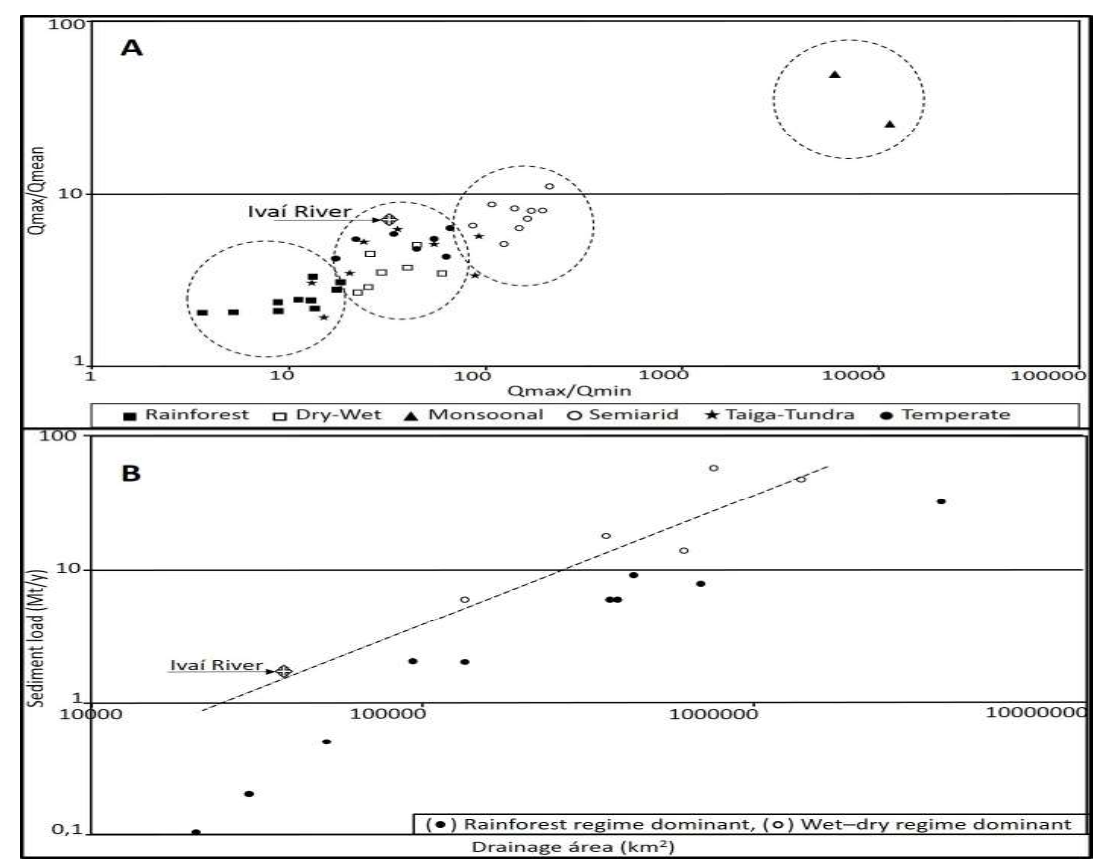

Figure 10 - The Ivai River plotted with large tropical rivers in the world in terms of (A) Discharge variability, and (B) Plateau-cratonic rivers. The Ivai River clusters and lines with wet-dray climate rivers (Mod. Latrubesse et al., 2005). 
Table 5: Comparison between the Araguaia and Ivaí Rivers.

\begin{tabular}{lllll}
\hline River & Qmean $\left(\mathbf{m}^{3} \mathbf{s}^{-1}\right)$ & Barea $\left(\mathbf{k m}^{2}\right)$ & Qss $(\mathbf{M t})$ & Source \\
\hline Araguaia & 1100 & 375,000 & 4.0 & Latrubesse et al., 2009 \\
Ivaí & 702.9 & 36,587 & 2.0 & Leli et al., 2011 \\
\hline
\end{tabular}

$(M t)=$ Million tons by year

\section{Conclusion}

The Ivaí River has a historical (34 years) mean discharge of $702.9 \mathrm{~m}^{3} \mathrm{~s}^{-1}$, with high variability generating a hydrograph with non-seasonal peaks of maximum discharge. The elongated morphology of the river basin induces a gradual and well-defined process of discharge contribution along the longitudinal profile at rates varying from 0.01 to $0.02 \mathrm{~m}^{3} \cdot \mathrm{km}^{-2}$ with a maximum value of $0.11 \mathrm{~m}^{3} \mathrm{~km}^{-2}$, this probably by base flow contribution. The largest amount of water that enters the main channel comes from smaller tributaries (basin area $<500 \mathrm{~km}^{2}$ ), with a total contribution of $387.3 \mathrm{~m}^{3} \mathrm{~s}^{-1}, 53 \%$ of the Ivaí mean discharge, while the main tributaries (Alonso, Corumbataí, Mourão, Antas, Índios and Ligeiro) add only $201.5 \mathrm{~m}^{3} \mathrm{~s}^{-1}$. In general, a reduction in the specific water discharge is observed downstream, from 0.028 to 0.015 $\mathrm{m}^{3}$ year ${ }^{-1} \mathrm{~km}^{-2}$, with the largest values coming from the Marrecas-Cachoeira $\left(0.028 \mathrm{~m}^{3} \mathrm{~s}^{-1} \mathrm{~km}^{-2}\right)$ and São João $\left(0.025 \mathrm{~m}^{3} \mathrm{~s}^{-1} \mathrm{~km}^{-2}\right)$ in the upper basin. On the other hand, the basin's largest tributaries present the lowest specific discharge: the Corumbataí River with $0.023 \mathrm{~m}^{3} \cdot \mathrm{s}^{-1} \cdot \mathrm{km}^{-2}$ and the Alonso River with $0.019 \mathrm{~m}^{3} \mathrm{~s}^{-1} \mathrm{~km}^{-2}$.

Suspended load discharge has a dispersive correlation with water discharge $\left(\mathrm{R}^{2}=0.72\right)$ to dry season with work-clock hysteresis in its hydrograph, and $\left(\mathrm{R}^{2}=0.65\right)$ to wet season. However, the correlation between the annual discharge of suspended sediment and the average water discharge is very high $\left(\mathrm{R}^{2}=0.97\right)$. It occurs because, even with a heterogeneous constitution in terms of relief and soil, the elongated basin morphology arises as the main variable on yield distribution of suspended sediment along the basin. The correlation between contribution of suspended sediment and basin area is also high $\left(\mathrm{R}^{2}=0.95\right)$ showing a regular contribution of suspended sediment along the basin. The observed anomalies for Tapira and Paraíso do Norte gauging stations are promoted by loss of water to the flood plain during the flood (over the threshold of $4,000 \mathrm{~m}^{3} \mathrm{~s}^{-1}$ ). The tributary basins with the largest suspended sediment production are the Corumbataí (Qss $=97.5 \times 10^{3}$ ton year $\left.^{-1}\right)$ and Alonso Rivers $\left(\mathrm{Qss}=96.5 \times 10^{3}\right.$ ton year $\left.^{-1}\right)$, followed by the Mourão, Patos, Ligeiro, and Antas Rivers totaling Qss $=147.6 \times 10^{3}$ ton year $^{-1}$. The left margin tributaries present larger values sediment yield to the Ivaí River (Figure 9). This may be due to the fact that the left margin is a high tectonic block (SOUZA JR. et al., 2013 ), and supposed to have a higher degree of erosion Specific discharge of suspended load increases with basin area in behavior opposite to other river systems. This occurs by anthropic (more intensive agricultural and pasture land) and geological-pedological (high erosivity of sandy soils) causes specific for lower basin.

The study on dynamics of water and suspended sediment, as presented in this paper, can be a useful tool on river basin management and planning. Through this study, it is possible to localize key points with problems concerning anthropogenic impacts, or even areas with high sensibility or fragility that can be preserved for occupational protection.

The present study emphasized not only the importance of suspended load functioning and distribution on the proper river flood plain, as well on the Parana River channel. In the first case, the channel filled with large amounts of sediment provide the plain, as in the case 1992 in which the channel has transferred a total of 200 $\mathrm{x} 10^{7} \mathrm{~m}^{3}$ of water, and 500,000 tons of suspended sediment to the plain. And in the case of the Paraná River, the Ivaí contributes 2,097,292.6 ton $\mathrm{y}^{-1}$ of suspended sediment. It is a volume of great importance to the Paraná, whose natural suspended load is greatly reduced by retention in the large dams in its upper basin.

\section{Acknowledgements}

We acknowledge the Brazilian Council of Science and Technology- CNPq (Proc. (CNPq490602/2007$0)$ for financial support. We would like to thank Dr. Edgardo M. Latrubesse by comment and suggestions, and the Group of Environmental Studies-GEMA of the University of Maringá by laboratories and field support. We would to thank to the first reviewer of the manuscript by its careful and important corrections and suggestions. 


\section{References}

Agostinho, A.A., ROdRigues, L. GOMES, L.C. THOMAZ, S.M. \& MIRANDA, L.E. Structure and functioning of the Paraná River and its floodplain (LTER site 6). Ed. UEM, Maringá, PR, Brazil, 275. 2004.

ANDRADE,A. R. Variabilidade da precipitação pluviométrica da bacia hidrográfica do rio Ivaí-PR. Master's Thesis (Geography) - State University of Maringá-PR, 2003.

BRASIL. Departamento Nacional de Água e Energia Elétrica. Bacias hidrográficas dos rios Ivaí, Piquiri e Paraná; dados atualizados até 1984, Boletim Fluviométrico, Brasília, série F-06, 1985.

BRAUN, O. P. G. Contribuição à Geomorfologia do Brasil Central. Revista Brasileira de Geografia, 32, 1-36, 1971.

BHERING, S.B.; SANTOS, H.G. dos. Mapa de solos do estado do Paraná: legenda atualizada. Rio de Janeiro, Embrapa, 2008.

CARAMORI, P. H. Caracterização Climática. In: Instituto Agronômico do Paraná. Potencial de uso agrícola das áreas de várzea do Estado do Paraná: bacia hidrográfica do baixo Ivaí. Boletim Técnico. Londrina, (24) 1, 65-69, 1989.

Companhia Paranaense de Energia. Diagnóstico do aproveitamento do baixo curso do rio Ivaí para transporte e geração de energia. Governo do estado do Paraná. Relatório Interno, COPEL-2. 401, 1984.

DOWNS, P. W.; GREGORY, K. J. River Channel Management. Arnold London, 2004.

DESTEFANI, E. V. Regime Hidrológico do Rio Ivaí-PR. Master's Dissertations (Geography) - State University of Maringá, Maringá-PR, 2005.

ESPINOZZA, V. R.; MARTINEZ, J-M.; GUYOT, J-L.; FRAIZE, P.; ARMIJOS, E. The integration of field measurements and satellite observations to determine river solid loads in poorly monitored basins, Journal of Hydrology, Amsterdam, 445, 221-228, 2012.

FERREIRA F.J.F. Integração de dados aeromagnéticos e geológicos: configuração e evolução tectônica do Arco de Ponta Grossa. Master's Dissertation, Institute of Geosciences, São Paulo University, São Paulo, 170, 1982.

FILIZOLA, N. O fluxo de sedimentos em suspensão nos rios da bacia Amazônica Brasileira. ANEEL, Brasília, 63, 1999.

INSTITUTO AGRONÔMICO DO PARANÁ - IAP. Cartas climáticas do Estado do Paraná.
Londrina, 49, 1994.

LATRUBESSE, E.M., AMSLER, M., MORAIS, R.P., AQUINO, $\mathrm{S}$. The geomorphic responses of large pristine alluvial river to tremendous deforestation in the South American tropics: The case of the Araguaia River. Geomorphology, 113(3-4):239252, 2009.

LATRUBESSE, E.M. Patterns of anabranching channels: The ultimate end-member adjustment of mega Rivers. Geomorphology, 101,130-145, 2008.

LATRUBESSE, E.M., STEVAUX, J.C., SANTOS, M.L., ASSINE, M.L. Grandes sistemas fluviais: Geologia, geomorfologia e paleoidrologia. In: Souza, C.R.G., Suguio, K., Oliveira, A.M.S. \& Oliveira, P.E. (Eds.), Quaternário do Brasil. Holus Editora, Ribeirão Preto, 276-297, 2005.

LATRUBESSE, E.M., STEVAUX, J.C. The Araguaia-Tocantins fluvial Basin. Boletim Goiano de Geografia, 19 (1): 120-127, 1999.

LELI, I. T.; STEVAUX, J. C.; NOBREGA, M. T.; SOUZA FILHO, E. E. Variabilidade temporal no transporte de sedimentos no rio Ivaí - Paraná (1977-2007). Revista Brasileira de Geociências, 41 (4), 619-628, 2011.

MEURER, M. De l'hydro-écorégion au tronçon fluvial: recherche méthodologique. Le cas du bassin versant de L'Ivaí, État Du Paraná, Brésil. Doctoral Thesis - Université Lumière Lyon 2, 2008.

MEURER, M. Ecorregiões da bacia hidrográfica do rio Ivaí, Paraná, Brasil: uma contribuição metodológica para a gestão de bacias hidrográficas. Boletim de Geografia Teorética, 35 (2), 245-257, 2010.

MEURER, M.; BRAVARD, J.-P.; STEVAUX, J.C. Granulometria dos sedimentos marginais do rio Ivaí com vistas à compreensão da dinâmica hidrosedimentar montante-jusante. Revista Brasileira de Geomorfologia, 12 (1), 39-44, 2011.

MONTANHER, O.C.; NOVO, E.M.L.M.; BARBOSA, C.C.F.; RENNÓ, C.D; SILVA, T.S.F. Empirical models for estimating the suspended sediment concentration in Amazonian white water rivers using Landsat 5/TM. International Journal of Applied Earth Observation and Geoinformation. 29, 67-77, 2014.

MONTANHER, O.C., SOUZA FILHO, E.E., NOVO, E.M.L.M. Padrões espaciais do tansporte, produçao e variabilidade de sedimentos suspensos dos rios amazônicos de águas brancas. Revista Brsileira de 
Geomorfologia. 17 (1) 347-368, 2017.

NEIFF, J.J.; POI de NEIFF, A.S.G. Connectivity processes as a basis for the management of aquatic plants. In: Thomaz, S.M., Bini, L.M. (Eds.), Ecologia e Manejo de Macrófitas Aquáticas. Ed. UEM, Brazil, 39-58, 2003.

PARK, E.; LATRUBUSSE, E.M. Modelling suspended sediment distribution patterns of the Amazonas River using MODISdata. Remote Sensing of Environment, 147, 232-242, 2014.

PAIVA, D. G. Análise do índice de relação entre o fluxo de base e desflorestamento por meio de imagens orbitais e análise hidrológica: Baixo curso do rio Ivaí. Master's Dissertation (Geography) - State University of Maringá, Maringá-PR, 2008.

PONTELLI, M.E.; PAISANI, J.C. Foz do Iguaçu: Geomorphological context of the Iguaçu Falls. In: Vieira, B.C., Salgado, A.A.R., Santos, L.J.C. Landscapes and landforms of Brazil. Springer, 331$338,2015$.
SOUZA JR., M.D., SANTOS, M.L., SALAMUNI, E., STEVAUX, J.C., MORALES, N. Análise morfotrctônica da bacia hidrográfica do rio Ivaí, PR - Curso inferior. Revista Brasileira de Geomorfologia. 14(2), 213-320, 2013

STEVAUX, J. C.; CORRADINI, F. A.; AQUINO, S. Connectivity Processes and riparian vegetation of the upper Paraná River, Brazil. Journal of South American Earth Sciences, 1-9, 2013.

STEVAUX, J. C.; MARTINS, P. D.; MEURER, M. Changes in large Tropical River: The Paraná River downstream from the Porto Primavera Dam, Brazil. Geomorphology, 113, 230-238, 2009.

STEVAUX J. C.; LATRUBESSE E. M. Iguazu falls: a history of differential fluvial incision. In: Migon P. (ed.) Geomorphological landscapes of the world, Springer, 101-110, 2010.

STEVAUX, J.C. The Upper Paraná River (Brazil): geomorphology, sedimentology and paleoclimatology. Quaternary International, 21:143-161, 1994. 